\title{
Impact of Pig Slurry from WangGoong Farm Cluster on Water Quality of the Iksan Stream
}

\author{
Hong Lim Choi*, A. Suresh, T. Babu and Mansyur \\ Department of Agricultural Biotechnology and Research Institute for Agriculture and Life Sciences, \\ Seoul National University, Seoul, Republic of Korea 151-921
}

\begin{abstract}
Livestock wastewater is being discharged without treatment from Hasen's pig farm cluster in WangGoong (WG) area into the Iksan Stream, eventually flowing into the ManGyung (MG) at the upstream junction. Although it is well known that before discharge, wastewater must satisfy the pig slurry discharge standards; because of ongoing remodeling, proper treatment is not being performed. According to public records, wastewater from the WG pig farm cluster is responsible for 3.6\% of MG River pollution and $2.0 \%$ of the SaeManGuem (SMG) Reservoir pollution. As a result, upstream water treatment quality has become primary concern for development of the SMG project. All physicochemical constituents and pathogenic microbes, such as chemical oxygen demand $\left(\mathrm{COD}_{\mathrm{Cr}}\right)$, biochemical oxygen demand $\left(\mathrm{BOD}_{5}\right)$, total suspended solids (TSS), total nitrogen (TN), total phosphorous (TP), fecal coliforms, Escherichia coli and Salmonella at the effluent of WG Plant (S-1) exceed the effluent standards. This is mainly due to insufficient wastewater treatment: the WG Plant is under renovation to increase water purification efficiency. By comparing the water quality at the S-7 junction, where the the Iksan Stream (pig farms) and the Wanggoong Stream (no pig farms) merge, it is clear that farming facilities and improper treatment can critically affect surrounding water quality. While it is clear throughout this study that the level of all physicochemical parameters and pathogenic microbes along the Stream decreased due to sedimentation, biodegradation and/or dilution. An alarming problem was discovered: the existence of pathogenic microbe $\operatorname{count}(E$ coli, Salmonella $)$ in the lagoon wastewater and the stream water. Not only were high concentrations of these pathogens themselves found, but the potential existence of more serious pathogens could rise to more dangerous conditions.
\end{abstract}

(Key words : Bacteria, Heavy metals, Organic matter, Water pollution, Livestock wastewater)

\section{INTRODUCTION}

Pollutants from livestock wastewater have been identified as a primary contributor to eutrophication in rivers, lakes, reservoirs and estuaries (Carpenter et al., 1998). In Republic of Korea, drainage channel for agriculture is a common landscape feature throughout many agricultural regions. WangGoong Farm ('WG' hereafter) is comprised of three pig-farm clusters, namely Iksan Farm, Geumoh Farm, and Shinchon Farm where 187 pig producers grow about 114,000 head. However, the pig producers who are mostly the $1^{\text {st }}$ or $2^{\text {nd }}$ generation Hansen's disease patients have discharged their pig wastewater without any treatment into public waterway. The pig slurry seriously contributes to the pollution of the the Iksan Stream and its tributaries as shown in Fig. 1.

In WG, untreated pig wastewater is introduced to WG Public Livestock Wastewater Treatment Plant ('WG Plant' hereafter) collected by the four main pipelines. The livestock wastewater is supposed to be properly treated at WG Plant

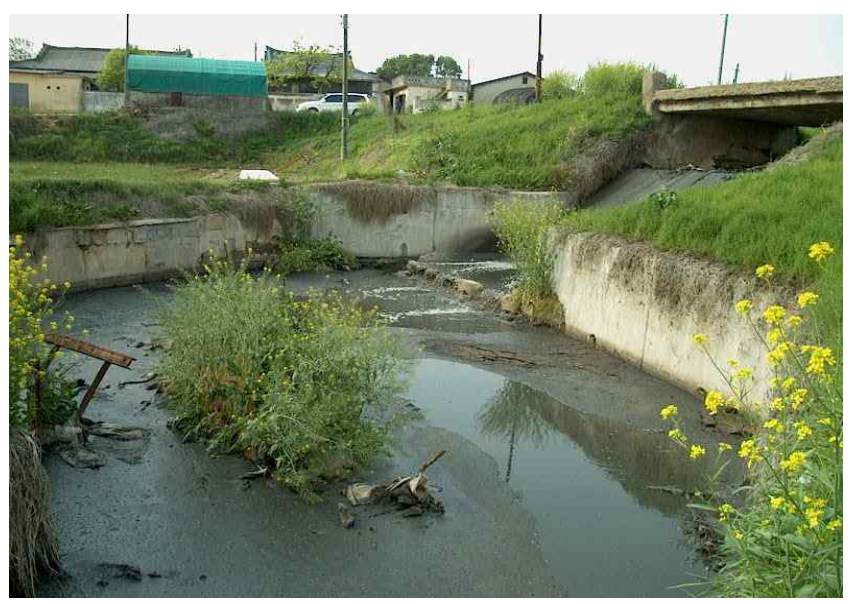

Fig. 1. Water stream seriously polluted with untreated pig slurry in WG.

\footnotetext{
* Corresponding author: Hong Lim Choi, Animal Environment and Bioengineering Lab, Department of Agricultural Biotechnology, Seoul National University, Gwanak-gu, Seoul 151-921, Republic of Korea; Tel: 02-880-4808; Fax: 02-874-4808; E-mail: ulsoo8@snu.ac.kr.
} 
and then discharged into the Iksan Stream. The water eventually leads to the Mangyung upstream river (' $\mathrm{MG}$ ' hereafter). The neighboring-residents have filed numerous complaints regarding the unbearable odor and severe water pollution caused by the illegal disposal of pig slurry from WG farm. This situation can amplify health-related problems, where eutrophic conditions interfere with drinking water treatment (Bartram et al., 1999). A noteworthy weakness remains the lack of attention paid so far to the role of rivers as aquatic habitat, no biological water standards have been adopted and water managers appear to have little awareness of aquatic species (WEPA, 2007).

Therefore, the purpose of the study is to figure out the current situation of biochemical and biological water quality of the ditches in WG Lagoons and the Iksan Stream. This process is expected to help build measures that will improve the water quality of the WG area and the Iksan Stream.

\section{MATERIALS AND METHODS}

\section{Sample collection and storage}

Eighteen wastewater samples including seven pig slurry samples in the lagoons ditches and eleven samples along the Iksan Stream and MG upstream samples, abbreviate coded in Fig. 2, were collected four times from April to July 2010. The total of seven samples were taken from three lagoons at upstream (U) and downstream (D) of Hakpyung-Je ('HPJ' hereafter (L-1-U, L-1-D), Yongho-Je ('YHJ' hereafter, L-2-U, L-2-D) and Jugyo-Je ('JGJ' hereafter, L-3-U1, L-3-U2, U-3D). Two samples were also taken from the effluent of WG Plant, one at S-1-1 (aerobically partially treated) and the second at S-1-2 (untreated). Because, WG Plant has been under renovation the wastewater was only partially treated and discharged into the Iksan Stream. The Stream water flows down to S-5 and merges with the stream water at S-6 from WG Stream where no pig producers exist and becomes the Stream water at S-7.

The Iksan Stream flows down and enters into the upstream of the MG River as shown in Fig. 2. A total of eleven samples were collected along the Iksan Stream (S-2 to S-9) and the MG River upstream (S-10). A water sampling kit (DAIHAN, Seoul, Republic of Korea) was used to collect one liter of wastewater using a sterile sampling bottle. The collected samples were stored in a cool box at $4^{\circ} \mathrm{C}$ until further use. The same sampling procedure was followed repeatedly for all the sites.

\section{Physico-biochemical analysis of water samples}

$\mathrm{pH}$ was measured using a $\mathrm{pH}$ meter(Inolab, WTW, $\mathrm{GmbH}$, Weilheim, Germany), TS, VS, TSS, TN, $\mathrm{NO}_{3}-\mathrm{N}$, $\mathrm{NH}_{3}-\mathrm{N}$, TP, available $\mathrm{P}$ and $\mathrm{BOD}_{5}$ were determined as per APHA (2005) procedure. $\mathrm{COD}_{\mathrm{Cr}}$, was analyzed using DR

\begin{tabular}{|c|c|}
\hline Sample site & Abbreviation \\
\hline \multicolumn{2}{|c|}{ Lagoons } \\
\hline Hakpyung Je & L-1-U \\
\hline Hakpyung Je & L-1-D \\
\hline Yongho Je & $\mathrm{L}-2-\mathrm{U}$ \\
\hline Yongho $\mathrm{Je}$ & L-2-D \\
\hline Jugyo Je & $\overline{L-3-U 1}$ \\
\hline Jugyo Je & L-3-U2 \\
\hline Jugyo Je & L-3-D \\
\hline \multicolumn{2}{|c|}{ Streams } \\
\hline WG LWWTP & $S-1-1$ \\
\hline WG LWWTP & S-1-2 \\
\hline Iksan Stream & $\mathrm{S}-2$ \\
\hline Iksan Stream & $\mathrm{S}-3$ \\
\hline Iksan Stream & $\mathrm{S}-4$ \\
\hline Iksan Stream & S-5 \\
\hline Iksan Stream & S-6 \\
\hline Iksan Stream & $\mathrm{S}-7$ \\
\hline Iksan Stream & $\mathrm{S}-8$ \\
\hline Iksan Stream & S-9 \\
\hline Mangyung River & S-10 \\
\hline
\end{tabular}

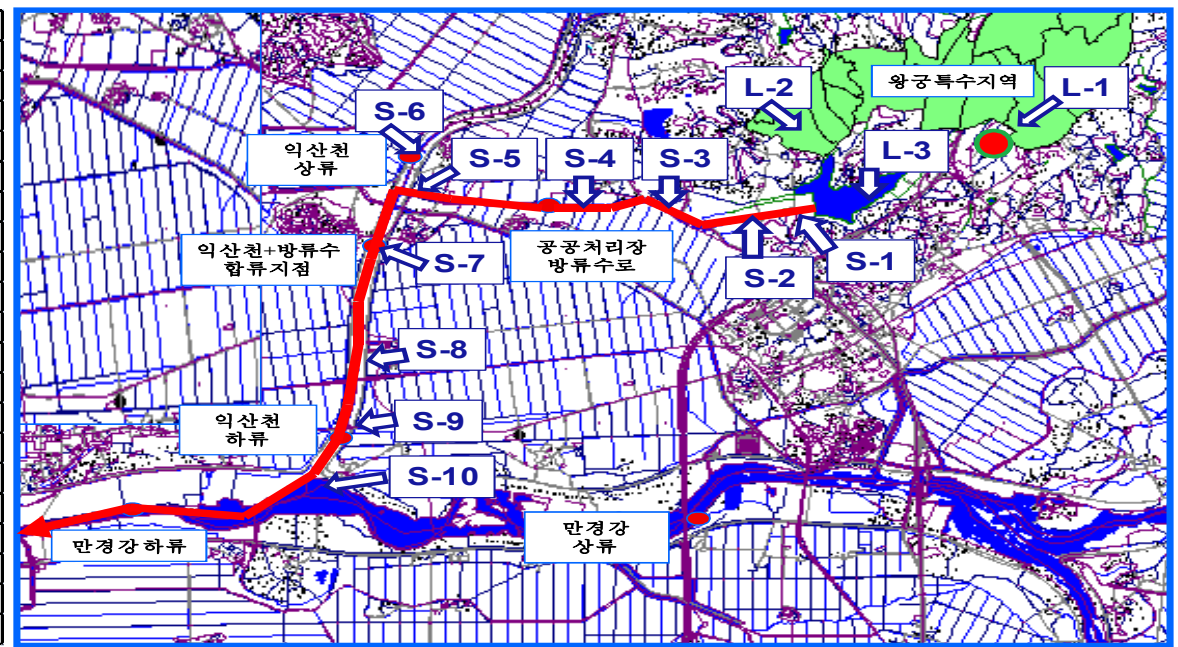

Fig. 2. Sampling sites of three lagoon ditches and the Iksan Stream in WG area. 
5000 UV-Vis spectrophotometer (Hach Co., Loveland, CO, USA.) per the manufacturer's protocol. To determine micronutrients and heavy metals $(\mathrm{Ca}, \mathrm{K}, \mathrm{Mg}, \mathrm{S}, \mathrm{B}, \mathrm{Cr}, \mathrm{Cu}$, $\mathrm{Fe}, \mathrm{Mn}, \mathrm{Mo}, \mathrm{Zn}, \mathrm{Pb}, \mathrm{Hg}, \mathrm{Cd}$, As and $\mathrm{Ni}$ ) content, $10 \mathrm{~mL}$ of the sample was first digested with concentrated nitric acid (APHA, 2005). Subsequently, the solution was made up to $100 \mathrm{~mL}$ in a volumetric flask and quantitatively analyzed by inductively coupled plasma (ICP) atomic emission spectroscopy (AES) (ICPS-7510, Shimadzu Corp., Kyoto, Japan).

\section{E. coli and Salmonella analysis}

$20 \mathrm{~mL}$ of well mixed slurry sample was transferred to 180 $\mathrm{mL}$ of sterile $25 \%$ Ringer solution $\left(\mathrm{NaCl} 2.25 \mathrm{~g}^{-1}, \mathrm{KCl} 0.105\right.$ $\mathrm{g}^{-1}, \mathrm{CaCl}_{2} 0.045 \mathrm{~g}^{-1}, \mathrm{NaHCO}_{3} 0.05 \mathrm{~g}^{-1}$, Citric acid $0.034 \mathrm{~g}^{-1}$ ) and $10 \mathrm{~mL}$ of this solution added into $90 \mathrm{~mL}$ of sterile $25 \%$ Ringer solution and subsequently serially diluted up to $10^{-5}$. For E. coli, $0.1 \mathrm{~mL}$ of each dilution was spread on Chromocult Coliforms Agar (CCA) (MERCK 1.10426) plates for slurry samples but for the water samples sterile membrane filters were used and placed on CCA plates (duplicate plates were used for each dilutions). The plates were incubated at $37^{\circ} \mathrm{C}$ for $24 \sim 48$ hrs. The blue and violet colonies were counted for $E$. coli according to manufacture instruction shown in Fig. 10A.

For Salmonella, a three tube MPN method was followed for the slurry samples. Three aliquots of $1 \mathrm{~mL}$ sample from each dilution added to three tubes contain $9 \mathrm{~mL}$ of Selenite Cystine Broth (Difco). These tubes were incubated at $37^{\circ} \mathrm{C}$ for 48 hrs. Tubes were mixed and one loopful of culture was streaked on Salmonella Shigella(SS) agar plate. Each plate was divided into three portions and each portion was streaked loopful of culture from the three different tubes and incubated at $37^{\circ} \mathrm{C}$ for $24 \mathrm{hrs}$. The black centered colonies were observed in plates as shown in Fig. 10B, noted as positive tubes, and were determined by the most probable number (MPN) of Salmonella using a standard MPN table. While the water samples were filtered using sterile membrane filter and placed on SS agar plates.

\section{RESULTS AND DISCUSSION}

The samples from the lagoons in WG and Iksan wastewater stream were analyzed for basic physico-biochemical parameters, nutrients, heavy metals and pathogens (bacteria) to investigate how much the Iksan Stream was polluted before entering the MG River. Table 3 shows the average amount of physico-biochemical properties and pathogens of the respective samples. Table 4 shows the average amount of micronutrients and heavy metals contents of the respective samples in WG area at each field survey.

\section{Physico-biochemical parameters}

(1) $\mathrm{pH}$

The ditch wastewater in WG lagoons, and the Iksan Stream water were analyzed for $\mathrm{pH}$, shown in Fig. 3 at each field survey. The average $\mathrm{pH}$ of $\mathrm{MG}$ upstream water (S-10) was observed at 7.29, which is nearly neutral. The $\mathrm{pH}$ of the stream waters at S-2, S-3, S-4 and S-5, were observed higher than 7.5, which demonstrates a slight alkaline nature. Since partially treated lagoon wastewater from WG plant showed higher $\mathrm{pH}$ of 8.0 at $\mathrm{S}-1-1$ because of ammonification, while untreated effluent at S-1-2 observed lowers $\mathrm{pH}$ of 7.5. The slurry samples from the lagoon and the stream were observed in the range of 7.32 7.37 which is

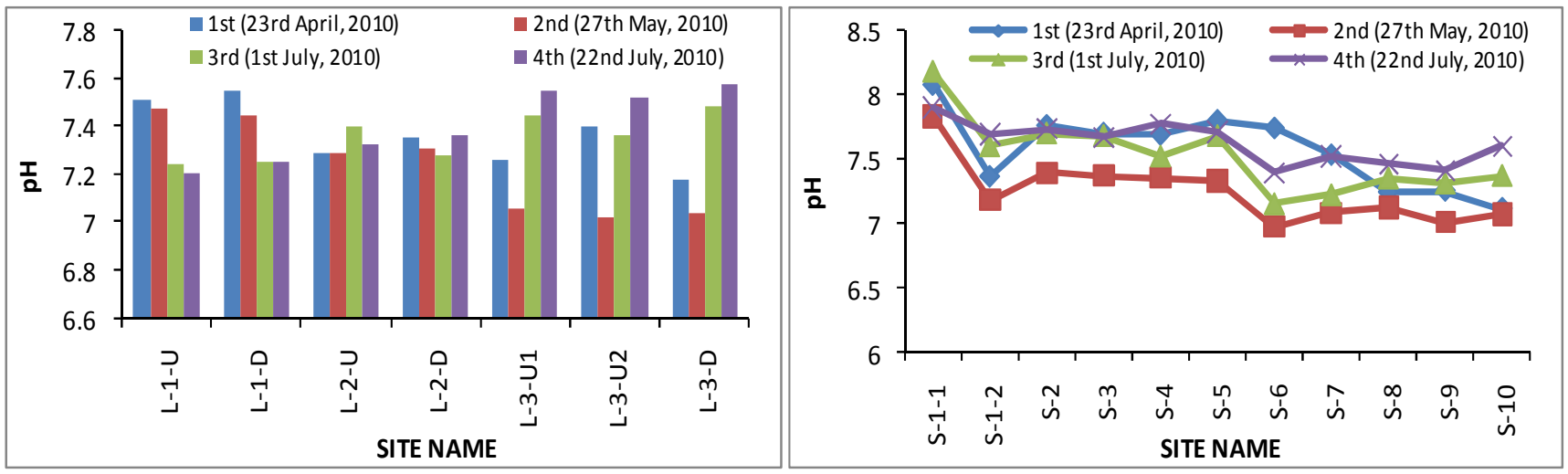

Fig. 3. Variations of $\mathrm{pH}$ of seven wastewater samples in WG lagoon ditches and eleven water samples along the Iksan Stream. 
Table 1. Korean Standard for the Rivers and Streams for the Living Environment*

\begin{tabular}{ccccc}
\hline \multirow{2}{*}{ Grade } & \multicolumn{3}{c}{ Standard } \\
\cline { 2 - 5 } & $\mathrm{pH}$ & BOD $_{5}(\mathrm{mg} / \mathrm{L})$ & TSS $^{2}(\mathrm{mg} / \mathrm{L})$ & Fecal Coliforms $($ No./100 $\mathrm{mL})$ \\
\hline \hline Very Good & $6.5 \sim 8.5$ & $\leq 1$ & $\leq 25$ & $\leq 10$ \\
Good & $6.5 \sim 8.5$ & $\leq 2$ & $\leq 25$ & $\leq 100$ \\
Fairly Good & $6.5 \sim 8.5$ & $\leq 3$ & $\leq 25$ & $\leq 200$ \\
Fair & $6.5 \sim 8.5$ & $\leq 5$ & $\leq 25$ & $\leq 1,000$ \\
Fairly Poor & $6.5 \sim 8.5$ & $\leq 8$ & $\leq 100$ & \\
Poor & $6.5 \sim 8.5$ & $\leq 10$ & No $^{1)}$ & \\
Very Poor & & $>10$ & & \\
\hline
\end{tabular}

* This table was reproduced from Ministry of Environment, Republic of Korea.

${ }^{1)}$ No floating matters such as garbage; ${ }^{2)}$ TSS, Total suspended solids.

appropriate for a living environment, although $\mathrm{pH}$ tended to decrease along the Iksan Stream towards the MG River. According to the Korean standard in Table 1, pH in the lagoon and stream appears to be within the proper range.

\section{(2) Solids}

Solids such as TS, VS and TSS, are representative indicators of the severity of pollution. Wastewater samples from the WG lagoon ditches and samples from the Iksan Stream were analyzed for TS, VS, and TSS at each field survey, as shown in Table 3 and Fig. 4. The average TS of the lagoon wastewater was about $0.64 \%$, which is much lower compared to $4.0 \%$ of TS in Korean swine slurry, reported by Suresh et al. (2009a; 2009b). This indicates that pig wastewater discharged into the lagoon ditches was diluted by a large amount of flushing water at the production site.

TS concentration at S-1-1 treated and S-1-2 untreated observed 2,400 mg/L and $5,000 \mathrm{mg} / \mathrm{L}$, respectively. The concentration was decreased and reaches about $321 \mathrm{mg} / \mathrm{L}$ at $\mathrm{S}-10$. Average concentration of $\mathrm{VS}$ at lagoon ditches were observed $4,140 \mathrm{mg} / \mathrm{L}$, whereas at the site of S-1-1 and S-1-2 were observed $1,259 \mathrm{mg} / \mathrm{L}$ and $3,020 \mathrm{mg} / \mathrm{L}$, respectively and reaches about $160 \mathrm{mg} / \mathrm{L}$ at S-10. The average VS/TS was $64 \%$ which is a bit lower than raw pig slurry at $75 \%$. This may be caused by the inclusion of domestic wastewater from residents.
Total suspended solid (TSS) is a legal constituent of the law regarding effluent water quality standard ("effluent standard' hereafter) in Republic of Korea. Suspended solids are important as pollutants and pathogens, and are carried on the surface of suspended particles. The finer the particle is, the greater the surface area per unit mass, so the greater the pollutant load that is likely to be carried (Michaud 1994) by suspended solids. The Lagoon wastewater samples had observed an average TSS of $2,614 \mathrm{mg} / \mathrm{L}$. Interestingly, effluent partially treated at S-1-1 and untreated at S-1-2 were measured $370 \mathrm{mg} / \mathrm{L}$ and $2,690 \mathrm{mg} / \mathrm{L}$, respectively, which violate the effluent standard (Table 2). While, TSS of the stream water at S-9 was $48 \mathrm{mg} / \mathrm{L}$, just before merger of the MG River, which categories fairly poor grade according to the living standard for the river water in Republic of Korea (Table 1). TSS was observed $797 \mathrm{mg} / \mathrm{L}$ at S-5 and $66 \mathrm{mg} / \mathrm{L}$ at S-6 (where is free of pig slurry), and ended up with 406 $\mathrm{mg} / \mathrm{L}$ at S-7 after merge of two tributaries. Naturally, TSS reduces the advancement of the Iksan Stream's flow into the MG River because of dilution with less polluted water introduction from the tributaries, biodegradation, and sedimentation of solid particles along the Iksan Stream.

\section{Oragnic Matter}

(1) $\mathrm{COD}_{\mathrm{Cr}}$

COD and BOD is commonly used to indirectly measure

Table 2. The effluent standard of WG Plant in S. Korea

\begin{tabular}{ccccccc}
\hline Parameters & $\mathrm{BOD}_{5}$ & $\mathrm{COD}_{\mathrm{Mn}}$ & TSS & TN & TP & E. coli \\
\hline \hline Threshold Values (mg/L) & $<30$ & $<50$ & $<30$ & $<60$ & $<8$ & $<3,000 \mathrm{CFU} / \mathrm{mL}$ \\
\hline
\end{tabular}



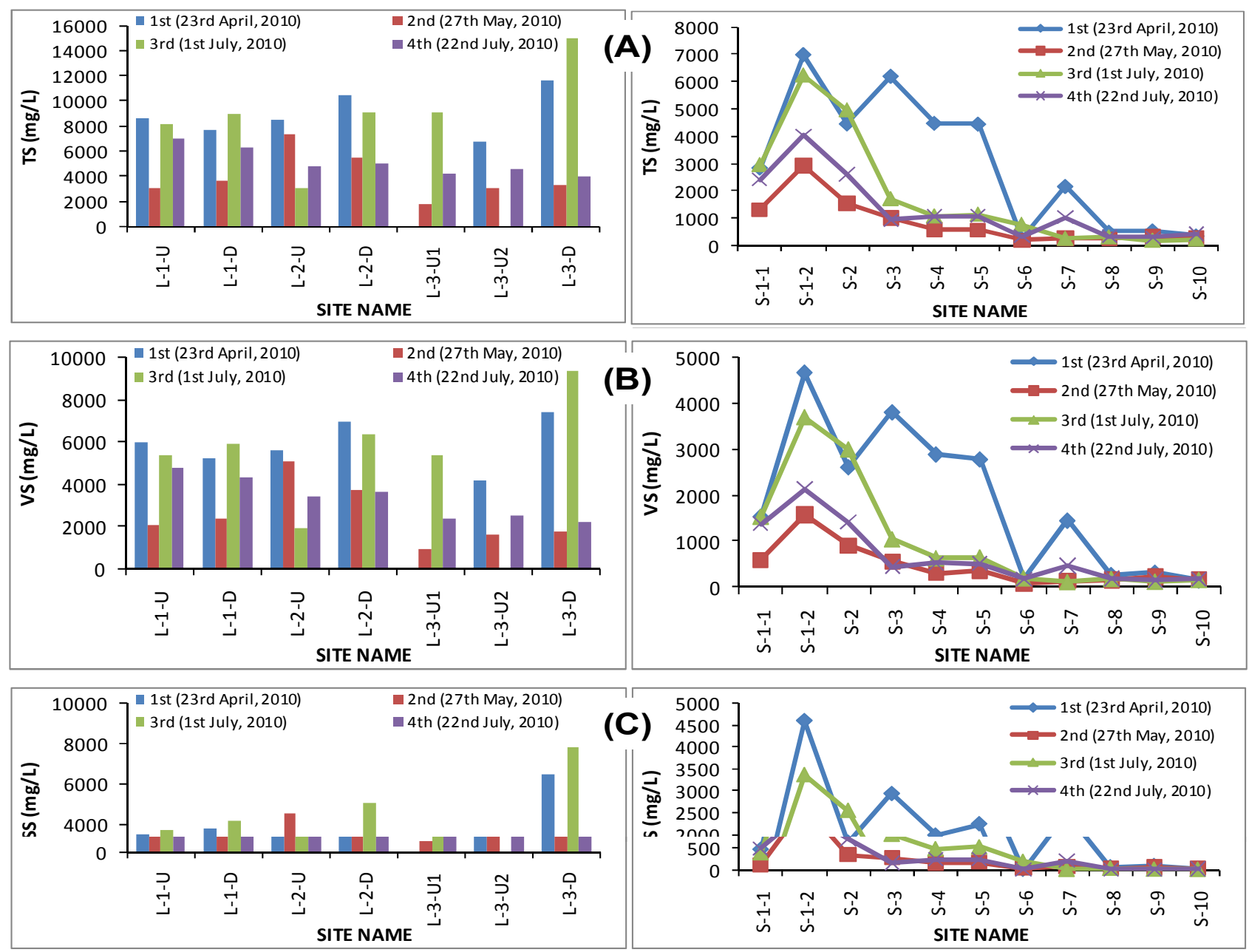

Fig. 4. Variations of Solid contents [TS (A), VS (B) and TSS(C)] of seven wastewater samples in WG lagoon ditches and eleven water samples along the Iksan Stream.

organic matter content in wastewater. Concentrations of these constituents are normally raised as a result of organic pollutants discharged by pig producers in WG area. The variation of $\mathrm{TCOD}_{\mathrm{Cr}}$ and $\mathrm{SCOD}_{\mathrm{Cr}}$ are shown in Fig. $5 \mathrm{~A}$ and Fig. 5B respectively for WG lagoon ditches and the Iksan Stream water. The mean $\mathrm{TCOD}_{\mathrm{Cr}}$ and $\mathrm{SCOD}_{\mathrm{Cr}}$ of the lagoons wastewater were $8,291 \mathrm{mg} / \mathrm{L}$ and $3,340 \mathrm{mg} / \mathrm{L}$, respectively, shown in Table 3. SCOD accounts for 40\% of $\mathrm{TCOD}_{\mathrm{Cr}}$ in pig slurry. $\mathrm{COD}_{\mathrm{Cr}}$ of effluents partially treated (S-1-1) and untreated (S-1-2) from the WG Plant were observed $1,586 \mathrm{mg} / \mathrm{L}$ and $4,774 \mathrm{mg} / \mathrm{L}$, respectively, and SCOD $_{\mathrm{Cr}}$ were $1,152 \mathrm{mg} / \mathrm{L}$ and $1,520 \mathrm{mg} / \mathrm{L}$. Those values did not meet the effluent standard, which should be $\mathrm{COD}_{\mathrm{Mn}}<50$ $\mathrm{mg} / \mathrm{L}$. At merge site of two tributaries at S-7, $\mathrm{COD}_{\mathrm{Cr}}$ was 
Table 3. The average values of physico-biochemical properties and microbes of all water samples taken at each field survey

\begin{tabular}{|c|c|c|c|c|c|c|c|c|c|c|c|c|c|c|c|c|c|}
\hline Category & Sample site & Abbreviation & $\mathrm{pH}$ & $\begin{array}{c}\mathrm{TS} \\
(\mathrm{mg} / \mathrm{L})\end{array}$ & $\begin{array}{c}\mathrm{VS} \\
(\mathrm{mg} / \mathrm{L})\end{array}$ & $\begin{array}{c}\text { VS/TS } \\
(\%)\end{array}$ & $\begin{array}{c}\text { TSS } \\
(\mathrm{mg} / \mathrm{L})\end{array}$ & $\begin{array}{l}\text { TCOD } \\
(\mathrm{mg} / \mathrm{L})\end{array}$ & $\begin{array}{l}\text { SCOD } \\
(\mathrm{mg} / \mathrm{L})\end{array}$ & $\begin{array}{c}\mathrm{BOD}_{5} \\
(\mathrm{mg} / \mathrm{L})\end{array}$ & $\begin{array}{c}\mathrm{TN} \\
(\mathrm{mg} / \mathrm{L})\end{array}$ & $\begin{array}{c}\mathrm{NO}_{3} \\
(\mathrm{mg} / \mathrm{L})\end{array}$ & $\begin{array}{c}\mathrm{NH}_{3} \\
(\mathrm{mg} / \mathrm{L})\end{array}$ & $\begin{array}{c}\mathrm{TP} \\
(\mathrm{mg} / \mathrm{L})\end{array}$ & $\begin{array}{c}\text { Available P } \\
(\mathrm{mg} / \mathrm{L})\end{array}$ & $\begin{array}{c}\text { E.coli } \\
\text { CFU/mL }\end{array}$ & $\begin{array}{c}\text { Salmonella } \\
\mathrm{MPN} / \mathrm{mL}\end{array}$ \\
\hline \multirow{7}{*}{ Lagoon } & Hakpyung Je & L-1-U & 7.36 & 6,727 & 4,537 & 67 & 2,731 & 10,581 & 3,565 & 4,810 & 1,453 & 384 & 493 & 320 & 128 & $1.47 \times 10^{5}$ & 1,648 \\
\hline & Hakpyung Je & L-1-D & 7.37 & 6,639 & 4,453 & 66.9 & 2,950 & 9,900 & 3,925 & 4,400 & 1,190 & 388 & 484 & 353 & 136 & $9.78 \times 10^{4}$ & 1,875 \\
\hline & Yongho Je & $\mathrm{L}-2-\mathrm{U}$ & 7.33 & 5,926 & 4,007 & 67.3 & 2,400 & 8,250 & 4,074 & 4,178 & 1,263 & 252 & 429 & 191 & 89 & $2.95 \times 10^{4}$ & 421 \\
\hline & Yongho Je & L-2-D & 7.33 & 7,503 & 5,151 & 68.9 & 3,013 & 12,531 & 6,016 & 6,373 & 1,524 & 379 & 561 & 288 & 134 & $3.12 \times 10^{4}$ & 1,296 \\
\hline & Jugyo Je & L-3-U1 & 7.33 & 5,035 & 2,887 & 54.2 & 1,357 & 3,942 & 1,380 & 1,900 & 711 & 206 & 275 & 232 & 93 & $3.04 \times 10^{4}$ & 653 \\
\hline & Jugyo Je & L-3-U2 & 7.33 & 4,795 & 2,761 & 58.4 & 1,483 & 5,125 & 2,670 & 1,603 & 807 & 260 & 352 & 148 & 78 & $2.73 \times 10^{4}$ & 408 \\
\hline & Jugyo Je & L-3-D & 7.32 & 8,459 & 5,186 & 59 & 4,368 & 7,706 & 1,750 & 2,255 & 1,469 & 191 & 314 & 292 & 192 & $4.28 \times 10^{4}$ & 510 \\
\hline \multirow{2}{*}{ LWWTP } & WG LWWTP & S-1-1 & 8 & 2,379 & 1,259 & 52 & 370 & 1,586 & 1,152 & 468 & 622 & 107 & 355 & 89 & 25 & $1.09 \times 10^{4}$ & 188 \\
\hline & WG LWWTP & S-1-2 & 7.46 & 5,043 & 3,020 & 58.2 & 2,690 & 4,774 & 1,520 & 1,940 & 919 & 240 & 300 & 164 & 103 & $2.26 \times 10^{4}$ & 389 \\
\hline \multirow{9}{*}{ Stream } & Iksan Stream & S-2 & 7.65 & 3,390 & 1,980 & 57.9 & 1,356 & 2,808 & 1,157 & 928 & 847 & 288 & 330 & 195 & 78 & $2 \times 10^{4}$ & 116 \\
\hline & Iksan Stream & S-3 & 7.61 & 2,462 & 1,459 & 55.7 & 1,051 & 2,439 & 1,270 & 912 & 418 & 130 & 238 & 92 & 44 & $1.4 \times 10^{4}$ & 85 \\
\hline & Iksan Stream & S-4 & 7.58 & 1798 & 1,084 & 55.6 & 719 & 1,523 & 699 & 625 & 435 & 120 & 187 & 121 & 31 & $7.48 \times 10^{3}$ & 22 \\
\hline & Iksan Stream & S-5 & 7.63 & 1,804 & 1,070 & 56.9 & 797 & 1,501 & 589 & 484 & 351 & 107 & 188 & 65 & 31 & $3.51 \times 10^{3}$ & 12 \\
\hline & Iksan Stream & S-6 & 7.31 & 392 & 156 & 45.6 & 66 & 44 & 26 & 19 & 23 & 7.2 & 84 & 5.1 & 2.8 & $9.7 \times 10^{1}$ & 0 \\
\hline & Iksan Stream & S-7 & 7.34 & 931 & 537 & 50.1 & 406 & 628 & 108 & 126 & 121 & 68 & 24 & 22 & 15 & $1.14 \times 10^{3}$ & 125 \\
\hline & Iksan Stream & S-8 & 7.29 & 350 & 192 & 55.3 & 41 & 107 & 90 & 37 & 46 & 6.8 & 11.8 & 6.9 & 4.2 & $1.04 \times 10^{3}$ & 32 \\
\hline & Iksan Stream & S-9 & 7.25 & 342 & 203 & 60.2 & 48 & 119 & 100 & 34 & 48 & 6.8 & 18.5 & 10 & 0.8 & $2.93 \times 10^{2}$ & 2.3 \\
\hline & Mangyung River & S-10 & 7.29 & 321 & 160 & 52.8 & 27 & 42 & 33 & 9 & 26 & 8.9 & 10.5 & 6.6 & 1.9 & $2.17 \times 10^{2}$ & 0.6 \\
\hline
\end{tabular}

$628 \mathrm{mg} / \mathrm{L}$, which was a resultant mixture of $1,501 \mathrm{mg} / \mathrm{L}$ at $\mathrm{S}-5$ and $107 \mathrm{mg} / \mathrm{L}$ at $\mathrm{S}-6 . \mathrm{COD}_{\mathrm{Cr}}$ at $\mathrm{S}-9$ was $119 \mathrm{mg} / \mathrm{L}$ just before merge of the MG River. These observations indicate that water quality of the Iksan Stream was severely polluted.

\section{(2) $\mathrm{BOD}_{5}$}

The variation of $\mathrm{BOD}_{5}$ is shown in Fig. 6 and Table 3 . The average BOD of the effluent treated at S-1-1 and untreated at S-1-2 were observed $468 \mathrm{mg} / \mathrm{L}$ and $1,940 \mathrm{mg} / \mathrm{L}$,

Table 4. The average values of nutrients and heavy metal contents of all water samples taken at each field survey

\begin{tabular}{|c|c|c|c|c|c|c|c|c|c|c|c|c|c|c|c|c|c|c|}
\hline Category & Sample site & Abbreviation & $\begin{array}{c}\mathrm{Ca} \\
(\mathrm{mg} / \mathrm{L})\end{array}$ & $\begin{array}{c}\mathrm{K} \\
(\mathrm{mg} / \mathrm{L})\end{array}$ & $\begin{array}{c}\mathrm{Mg} \\
(\mathrm{mg} / \mathrm{L})\end{array}$ & $\begin{array}{c}\mathrm{S} \\
(\mathrm{mg} / \mathrm{L})\end{array}$ & $\begin{array}{c}\mathrm{B} \\
(\mathrm{mg} / \mathrm{L})\end{array}$ & $\begin{array}{c}\mathrm{Cr} \\
(\mathrm{mg} / \mathrm{L})\end{array}$ & $\begin{array}{c}\mathrm{Cu} \\
(\mathrm{mg} / \mathrm{L})\end{array}$ & $\begin{array}{c}\mathrm{Fe} \\
(\mathrm{mg} / \mathrm{L})\end{array}$ & $\begin{array}{c}\mathrm{Mn} \\
(\mathrm{mg} / \mathrm{L})\end{array}$ & $\begin{array}{c}\mathrm{Mo} \\
(\mathrm{mg} / \mathrm{L})\end{array}$ & $\begin{array}{c}\mathrm{Zn} \\
(\mathrm{mg} / \mathrm{L})\end{array}$ & $\begin{array}{c}\mathrm{Pb} \\
(\mathrm{mg} / \mathrm{L})\end{array}$ & $\begin{array}{c}\mathrm{Hg} \\
(\mathrm{mg} / \mathrm{L})\end{array}$ & $\begin{array}{c}\mathrm{Cd} \\
(\mathrm{mg} / \mathrm{L})\end{array}$ & $\begin{array}{c}\text { As } \\
(\mathrm{mg} / \mathrm{L})\end{array}$ & $\begin{array}{c}\mathrm{Ni} \\
(\mathrm{mg} / \mathrm{L})\end{array}$ \\
\hline \multirow{7}{*}{ Lagoon } & Hakpyung Je & L-1-U & 16.41 & 187.3 & 6.34 & 14.53 & 0.63 & 0.136 & 0.32 & 1.98 & 0.25 & 0.012 & 0.74 & 0.009 & 0.0004 & 0.002 & 0.014 & 0.084 \\
\hline & Hakpyung Je & L-1-D & 19.72 & 171.1 & 7.77 & 15.81 & 0.66 & 1.739 & 0.37 & 8.13 & 0.42 & 0.015 & 0.77 & 0.008 & 0.0004 & 0.003 & 0.011 & 0.928 \\
\hline & Yongho Je & L-2-U & 15.79 & 174.5 & 7.25 & 16.47 & 0.63 & 0.08 & 0.31 & 1.96 & 0.27 & 0.006 & 0.51 & 0.01 & 0.0005 & 0.001 & 0.008 & 0.059 \\
\hline & Yongho Je & L-2-D & 22.92 & 193.5 & 8.92 & 16.97 & 0.7 & 0.043 & 0.5 & 2.17 & 0.4 & 0.007 & 0.61 & 0.008 & 0.0001 & 0.001 & 0.009 & 0.036 \\
\hline & Jugyo Je & L-3-U1 & 19.31 & 164.3 & 6.82 & 11.34 & 0.83 & 0.05 & 0.36 & 3.68 & 0.31 & 0.006 & 0.75 & 0.01 & 0.0004 & 0.007 & 0.009 & 0.038 \\
\hline & Jugyo Je & L-3-U2 & 44.55 & 120 & 10.68 & 24.25 & 0.38 & 0.05 & 0.94 & 18.96 & 2.16 & 0.019 & 1.99 & 0.023 & 0.0004 & 0.018 & 0.013 & 0.039 \\
\hline & Jugyo Je & L-3-D & 19.37 & 132.6 & 8 & 18.49 & 0.48 & 0.049 & 0.43 & 5.65 & 1.97 & 0.007 & 0.79 & 0.07 & 0.0003 & 0.001 & 0.006 & 0.035 \\
\hline \multirow{2}{*}{ LWWTP } & WG LWWTP & S-1-1 & 7.55 & 130.9 & 2.81 & 37.73 & 0.94 & 0.042 & 0.02 & 0.29 & 0.04 & 0.002 & 0.06 & 0.015 & 0.0013 & 0.001 & 0.007 & 0.032 \\
\hline & WG LWWTP & S-1-2 & 16.5 & 130.9 & 7.1 & 14.42 & 0.75 & 0.047 & 0.32 & 3.14 & 0.29 & 0.006 & 0.62 & 0.015 & 0.0007 & 0.001 & 0.01 & 0.034 \\
\hline \multirow{9}{*}{ Stream } & Iksan Stream & S-2 & 6.94 & 122.5 & 3.03 & 10.71 & 0.72 & 0.139 & 0.1 & 1.48 & 0.11 & 0.003 & 0.21 & 0.011 & 0.0008 & ND & 0.007 & 0.085 \\
\hline & Iksan Stream & $\mathrm{S}-3$ & 7.87 & 146.3 & 3.08 & 17.47 & 0.86 & 0.058 & 0.1 & 1.26 & 0.1 & 0.007 & 0.26 & 0.011 & 0.0002 & ND & 0.008 & 0.045 \\
\hline & Iksan Stream & S-4 & 7.86 & 117.6 & 2.93 & 10.26 & 0.82 & 0.091 & 0.12 & 1.28 & 0.11 & 0.003 & 0.24 & 0.01 & 0.0004 & 0.008 & 0.005 & 0.054 \\
\hline & Iksan Stream & S-5 & 6.4 & 110.6 & 2.39 & 7.18 & 0.73 & 0.076 & 0.08 & 1.05 & 0.08 & 0.004 & 0.15 & 0.007 & 0.0001 & 0.002 & 0.009 & 0.047 \\
\hline & Iksan Stream & S-6 & 2.93 & 4.4 & 0.73 & 6.49 & 0.7 & 0.094 & 0.02 & 1.05 & 0.03 & 0.003 & 0.05 & 0.008 & 0.0004 & 0.045 & 0.006 & 0.059 \\
\hline & Iksan Stream & S-7 & 4.5 & 21.1 & 1.17 & 6.39 & 0.51 & 0.072 & 0.06 & 1.08 & 0.06 & 0.002 & 0.13 & 0.006 & 0.0001 & ND & 0.003 & 0.043 \\
\hline & Iksan Stream & S-8 & 2.86 & 11.1 & 0.77 & 6.72 & 0.46 & 0.502 & 0.02 & 2.12 & 0.06 & 0.005 & 0.06 & 0.008 & 0.0001 & ND & 0.004 & 0.28 \\
\hline & Iksan Stream & S-9 & 2.97 & 14.7 & 0.78 & 3.59 & 0.57 & 4.482 & 0.03 & 16.11 & 0.42 & 0.013 & 0.06 & 0.008 & 0.0002 & 0.001 & 0.005 & 2.799 \\
\hline & Mangyung River & S-10 & 2.49 & 4.4 & 0.56 & 4.06 & 0.55 & 0.053 & 0.01 & 0.33 & 0.02 & 0.002 & 0.04 & 0.005 & 0.0002 & 0.001 & 0.006 & 0.036 \\
\hline
\end{tabular}




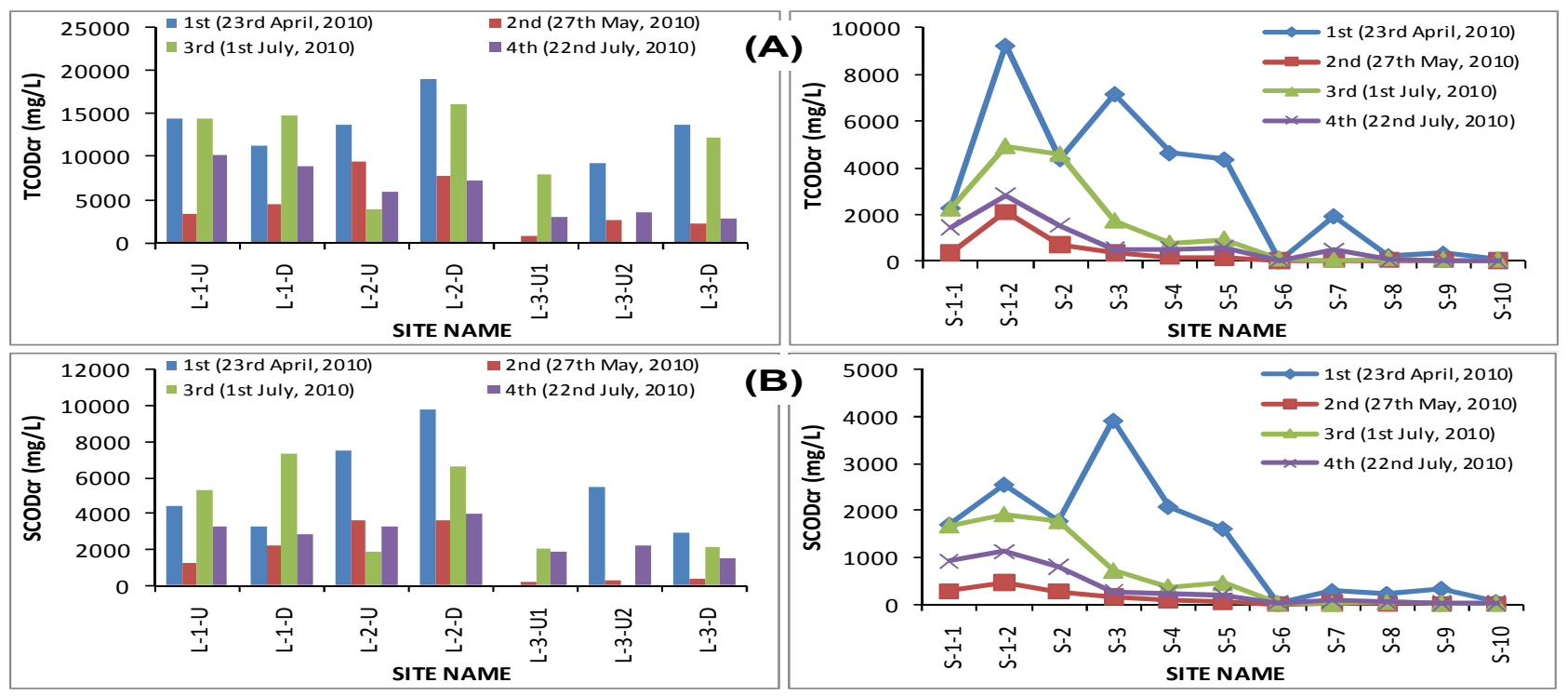

Fig. 5. Variations of Organic Parameters $\left[\operatorname{TCOD}_{\mathrm{Cr}}(\mathrm{A})\right.$ and $\left.\mathrm{SCOD}_{\mathrm{Cr}}(\mathrm{B})\right]$ contents of seven wastewater samples in WG lagoon ditches (Left) and eleven water samples along the Iksan Stream (Right).
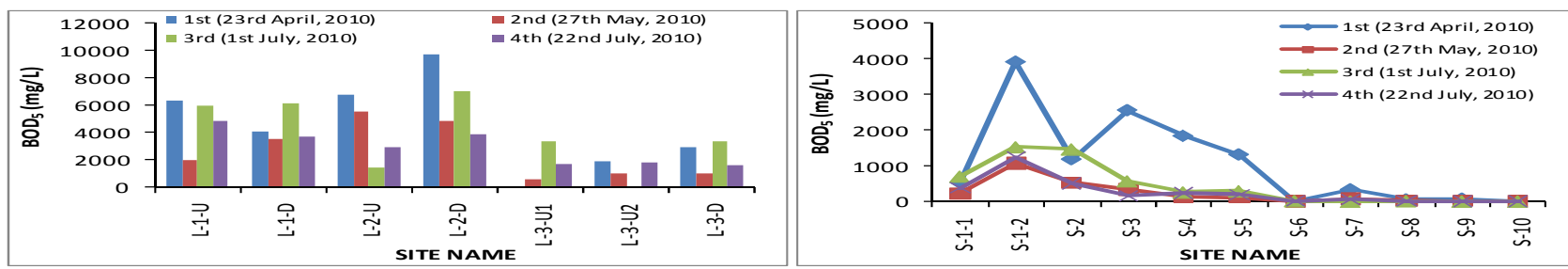

Fig. 6. Concentration of $\mathrm{BOD}_{5}$ in seven wastewater samples in WG lagoon ditches (Left) and eleven water samples along the Iksan Stream (Right).

respectively. This amount exceed that the effluent standard which should be lower than $30 \mathrm{mg} / \mathrm{L}$. At merge site of two tributaries at S-7, BOD was $126 \mathrm{mg} / \mathrm{L}$, which is a mixture of $589 \mathrm{mg} / \mathrm{L}$ at $\mathrm{S}-5$ and $26 \mathrm{mg} / \mathrm{L}$ at $\mathrm{S}-6$. The BOD at S-9 was $34 \mathrm{mg} / \mathrm{L}$ which categories very poor (Table 1). High
BOD indicates not only poor water quality but also reduction of the biodiversity of aquatic communities and microbiological quality (EEA, 2003). The survey found that water of the Iksan Stream was severely polluted due to swine slurry ditch. 


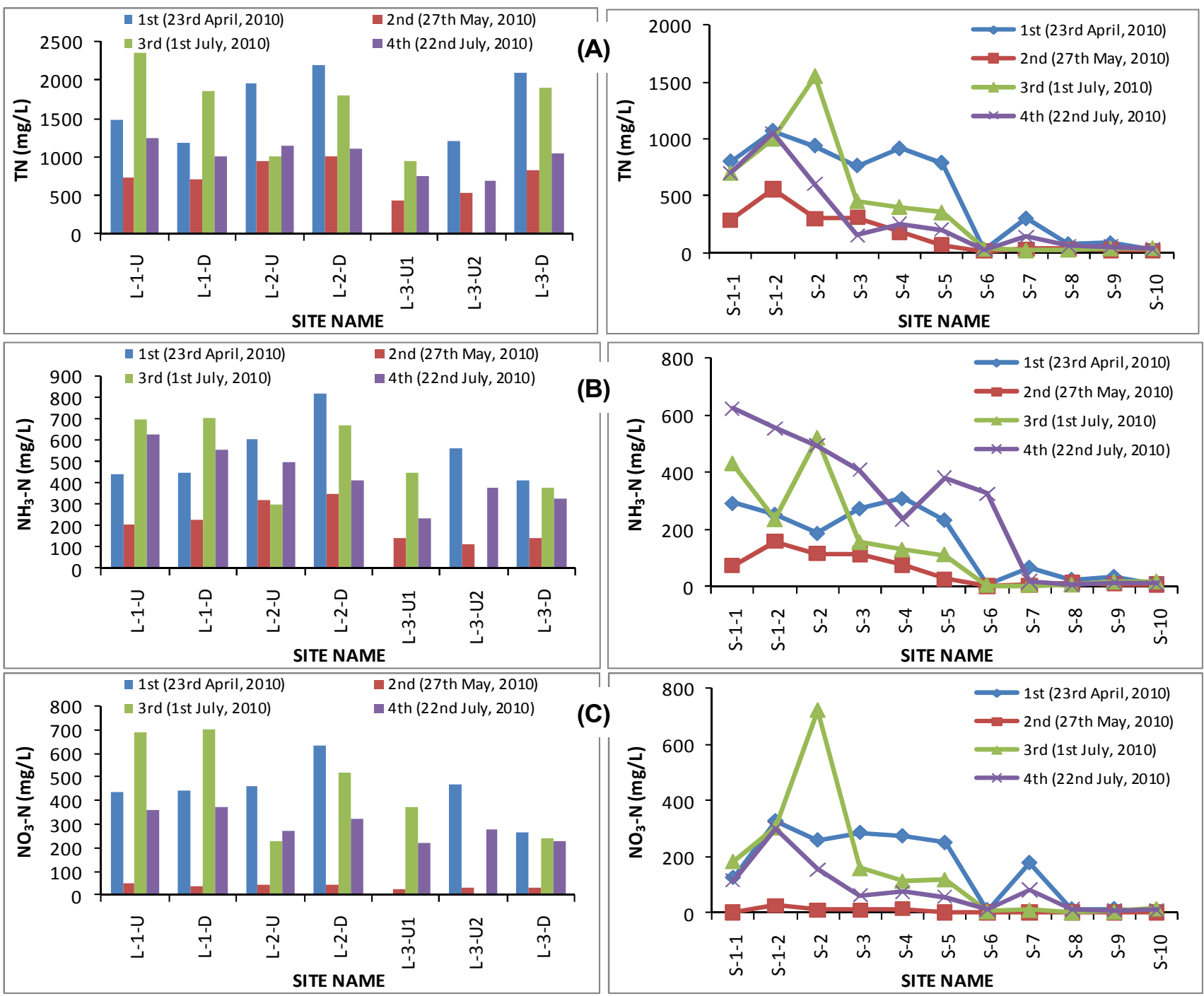

Fig. 7. Concentrations of nitrogen $\left[\mathrm{TN}(\mathrm{A}), \mathrm{NH}_{3}-\mathrm{N}(\mathrm{B}), \mathrm{NO}_{3}-\mathrm{N}(\mathrm{C})\right]$ contents in seven wastewater samples in WG lagoon ditches (Left) and eleven water samples along the Iksan Stream (Right).

\section{Macronutrients}

\section{(1) Nitrogen}

Nitrogen and its variants $\left(\mathrm{NH}_{3}{ }^{+}, \mathrm{NO}_{3}{ }^{-}\right)$concentrations are of great interest in wastewater because it is another tool for indicating water pollution, especially fresh water. Samples were analyzed for total nitrogen and shown in Table 3, Fig. 7A. The average TN of the Lagoon wastewater was observed $1,203 \mathrm{mg} / \mathrm{L}$, whereas at S-1-1 and S-1-2 were analyzed 622 $\mathrm{mg} / \mathrm{L}$ and $919 \mathrm{mg} / \mathrm{L}$, respectively. Which is far more exceeds the effluent standard' of WG Plant about $<60 \mathrm{mg}$ nitrogen/L. At merge site (S-7) of two tributaries, TN was $126 \mathrm{mg} / \mathrm{L}$, which is a mixture of $351 \mathrm{mg} / \mathrm{L}$ at S-5 and $23 \mathrm{mg} / \mathrm{L}$ at S-6.
Ammonia nitrogen $\left(\mathrm{NH}_{3}-\mathrm{N}\right)$ contributes significantly to the nutritional needs of living organisms by serving as a precursor to food and fertilizers. However, excess ammonia is an important nutrient pollutant in stream water and it pollutes the air of the surrounding environment by way of bad odor (Strock et al., 2007; Zhu et al., 2009). The average concentration of $\mathrm{NH}_{3}-\mathrm{N}$ was observed at $415 \mathrm{mg} / \mathrm{L}$ in the lagoon samples (Table 3, Fig. 7B) and it accounts for 35\% in TN. The partially treated effluent(S-1-1) and untreated (S-1-2) were observed at $355 \mathrm{mg} / \mathrm{L}$ and $300 \mathrm{mg} / \mathrm{L}$, respectively. At merge site (S-7), $\mathrm{NH}_{3}-\mathrm{N}$ was $24 \mathrm{mg} / \mathrm{L}$, which is a resultant mixture of $188 \mathrm{mg} / \mathrm{L}$ at S-5 and $8.4 \mathrm{mg} / \mathrm{L}$ at S-6 without intrusion of pig slurry. $\mathrm{NH}_{3}-\mathrm{N}$ at $\mathrm{S}-9$ was analyzed $18.5 \mathrm{mg} / \mathrm{L}$. The average nitrate $\left(\mathrm{NO}_{3}\right)$ was observed at 294 
$\mathrm{mg} / \mathrm{L}$ in the lagoon wastewater samples (Fig. 7C). Nitrate nitrogen accounts for $24 \%$ of $\mathrm{TN}$. The effluent partially treated (S-1-1) and untreated (S-1-2) were observed $107 \mathrm{mg} / \mathrm{L}$ and $240 \mathrm{mg} / \mathrm{L}$, respectively. The Iksan Stream water at S-5 with $107 \mathrm{mg} / \mathrm{L}$ of $\mathrm{NO}_{3}$ merged with the stream water at S-6 with $7.2 \mathrm{mg} / \mathrm{L}$, and led to $68 \mathrm{mg} / \mathrm{L}$ of $\mathrm{NO}_{3}$ at $\mathrm{S}-7$. The final river water(S-10) was observed $\mathrm{NO}_{3}$ at $8.9 \mathrm{mg} / \mathrm{L}$, concurrently the final stream water(S-9) to the river end at $6.8 \mathrm{mg} / \mathrm{L}$, respectively. Nitrogen content decreased to increasing distance from pollution sources (lagoon) due to natural process of denitrification, ammonification and nitrification process (WEPA, 2007; Merseburger et al., 2005; Earl et al., 2006.), managing these process can control a point and nonpoint source nitrogen (Strock et al., 2007).

\section{(2) Phosphorous}

The discharge of wastewater containing phosphorus may have legal implication if quantities sufficient to cause taste and odor problems in drinking water supplies occur. For this reason, phosphorus removal is essential in wastewater treatment, before introduced into the fresh water stream (McDowell and Sharpley 2003). The average TP was observed $261 \mathrm{mg} / \mathrm{L}$ in the lagoon samples, shown in Table 3 and Fig. 8. The effluent partially treated (S-1-1) and untreated outlet (S-1-2) were measured $89 \mathrm{mg} / \mathrm{L}$ and 164 $\mathrm{mg} / \mathrm{L}$, respectively, which violates the effluent standard $<8$ $\mathrm{mg} / \mathrm{L}$. Average available $\mathrm{P}\left(\mathrm{PO}_{4}{ }^{3-}\right)$ was also observed 121 $\mathrm{mg} / \mathrm{L}$ in the lagoon samples and its accounts for $46 \%$ of TP. The treated outlet (S-1-1) and untreated outlets (S-1-2) are observed at $25 \mathrm{mg} / \mathrm{L}$ and $103 \mathrm{mg} / \mathrm{L}$, respectively. In case of stream water samples, the available $\mathrm{P}$ was observed the reduced amount towards the end of the river side at 1.9 mg/L (Fig. 8).

\section{Micronutrients and Heavy Metals}

Micronutrients and heavy metal contaminations included in livestock wastewater are a major problem for stream water quality. Streams play a major role in nutrient export from polluted sites to the unpolluted sites (Hall, 2003; Begum et al., 2009). As a result, the Iksan lagoon slurry and stream water were evaluated to observe whether the following parameters, $\mathrm{Ca}, \mathrm{K}, \mathrm{Mg}, \mathrm{S}, \mathrm{B}, \mathrm{Cr}, \mathrm{Cu}, \mathrm{Fe}, \mathrm{Mn}, \mathrm{Mo}, \mathrm{Zn}, \mathrm{Pb}$, $\mathrm{Hg}, \mathrm{Cd}$, As and $\mathrm{Ni}$ existed. Nutrients and heavy metals, except some micronutrients $(\mathrm{Cr}, \mathrm{Mn}, \mathrm{Fe}, \mathrm{Ni})$ were observed in large amounts in lagoon slurry while reduced amounts were discovered towards the end of the MG River (Table 4), which may be caused by site contamination due to industrial

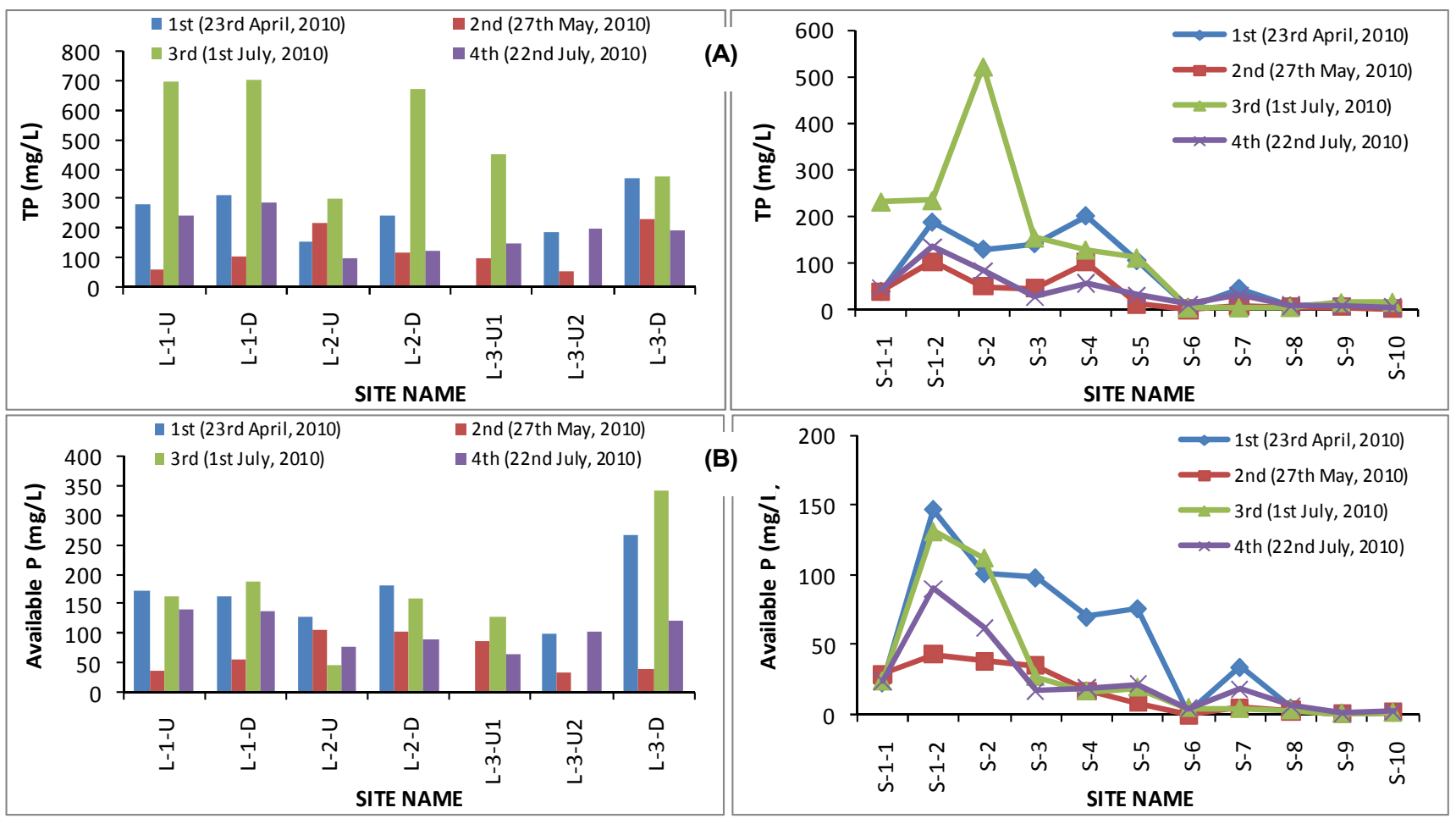

Fig. 8. Concentrations of phosphorous [TP (A), and available phosphorous (B)] contents in seven wastewater samples in WG lagoon ditches (Left) and eleven water samples along the lksan Stream (Right). 
or anthropogenic waste.

\section{(1) Micronutrients}

Dietary minerals of micronutrients supports metabolism in animals, as a result the feed contains many added minerals, which eventually comes to the feces and enters the waste streams that cause water pollution. The pollution degree of nutrients was within the acceptable range for most of the samples. The aerobically treated (S-1-1) and untreated (S-1-2) samples showed reduced amounts of nutrients except potassium (K), sulfur (S) and boron (B) This increase might be caused by the treatment process and some microbial activities. However the treatment Plant effectively reduced or removed many nutrients (Table 3 and 4), further accentuating the point that livestock wastewater should be treated before discharge into water streams. Interestingly, sample S-9 observed very high nutrient pollution particularly $\mathrm{Cr}, \mathrm{Mn}, \mathrm{Fe}$ and Ni. This indicated that the sampling site of S-9 was contaminated from other sources for an example, inclusion of industrial waste, intensive agricultural activities or anthropogenic wastes.

\section{(2) Heavy metal}

The pollution of aquatic environment with heavy metals has become a worldwide problem during recent years, because they are indestructible and most of them have toxic effects on organisms. Among environmental pollutants, metals are of particular concern, due to their potential toxic effect and ability to bioaccumulation in aquatic ecosystems. Therefore many countries make standard water quality for heavy metal content. The standard for heavy metal concentration in river and streams water for at Republic of Korea can be seen at Table 5. The aerobically treated (S-1-1) and untreated (S-1-2) samples showed reduced amounts of heavy metals except mercury (Hg) (Table 4). This increase might be the treatment

Table 5. The standard of heavy metal concentration in river and streams water in Republic of Korea*

\begin{tabular}{ll}
\hline Pollutants & Standard Value $(\mathrm{mg} / \mathrm{L})$ \\
\hline \hline Cadmium $(\mathrm{Cd})$ & $\leq 0.005$ \\
Arsenic $(\mathrm{As})$ & $\leq 0.05$ \\
Mercury $(\mathrm{Hg})$ & ND $($ LOD 0.001) \\
Lead $(\mathrm{Pb})$ & $\leq 0.05$ \\
\hline
\end{tabular}

ND : not detected; LOD : limit of detection.

* This table was reproduced from the Ministry of Environment, Republic of Korea. process or microbial activities or anthropogenic activity release mercury directly into water, for instance the application of agricultural fertilizers and industrial wastewater disposal. However the treatment Plant effectively reduced or removed some heavy metals, therefore the livestock wastewater should be treated before discharge into and water streams.

\section{(3) Microbes}

Although the vast majority of bacteria are harmless or beneficial, a few pathogenic bacteria can cause infectious diseases, mostly, from contaminated waters. E. coli can be used as indicator for contaminated water, if $E$. coli is found in water samples, it indicates that the Stream water is polluted with feces of warm-blooded animals and other pathogens (Salmonella, Cholera etc). These pathogens can cause acute infection in water bodies (Johnson et al., 2007).

\section{(4) E. coli}

Pathogenic indicator microbes along the Iksan Stream were observed to discover the severity of pollutions entering from WG pig farm clusters. As shown in Fig. 9A and Fig. 10A, $E$. coli was counted in the lagoon ditch wastewater, and the stream water. The average quantity of $E$. coli was observed at $5.8 \times 10^{4} \mathrm{CFU} / \mathrm{mL}$ in the lagoon wastewater samples (Table 3). As expected, E. coli count is reduced along the flow down from the lagoon ditch and the Iksan Stream due to dilution, sedimentation, and disinfection. The partially treated effluent at S-1-1 and untreated at S-1-2 counted $1.1 \times 10^{4}$ $\mathrm{CFU} / \mathrm{mL}$ and $2.3 \times 10^{4} \mathrm{CFU} / \mathrm{mL}$, respectively. It should be less than $3000 \mathrm{CFU} / \mathrm{mL}$, which indicates that even partial treatment at WG Plant does not completely eliminate E. coli. At merge site (S-7), E. coli was $1.14 \times 10^{3} \mathrm{CFU} / \mathrm{mL}$, which is a resultant mixture of $3.51 \times 10^{3} \mathrm{CFU} / \mathrm{mL}$ at S-5 and $9.7 \times 10^{1}$ $\mathrm{CFU} / \mathrm{mL}$ at S-6 without intrusion of pig slurry. E. coli at S-9 was analyzed at $2.93 \times 10^{2} \mathrm{CFU} / \mathrm{mL}$. It indicates that the stream water is polluted with fecal matter. The living standard in Table 1 for fecal coliforms is $\leq 1000 \mathrm{CFU} / 100$ $\mathrm{mL}$, which would be a fair grade. However, the stream water samples range falls in the very poor grade $(>1000$ $\mathrm{CFU} / 100 \mathrm{~mL}$ ) according to the living standards.

\section{(5) Salmonella}

Salmonella was observed in all samples as shown in Table 3 Fig. 9B and Fig. 10B except S-6. The average quantity of Salmonella was observed $973 \mathrm{MPN} / \mathrm{mL}$ in the lagoon wastewater samples. As expected, Salmonella count reduces 


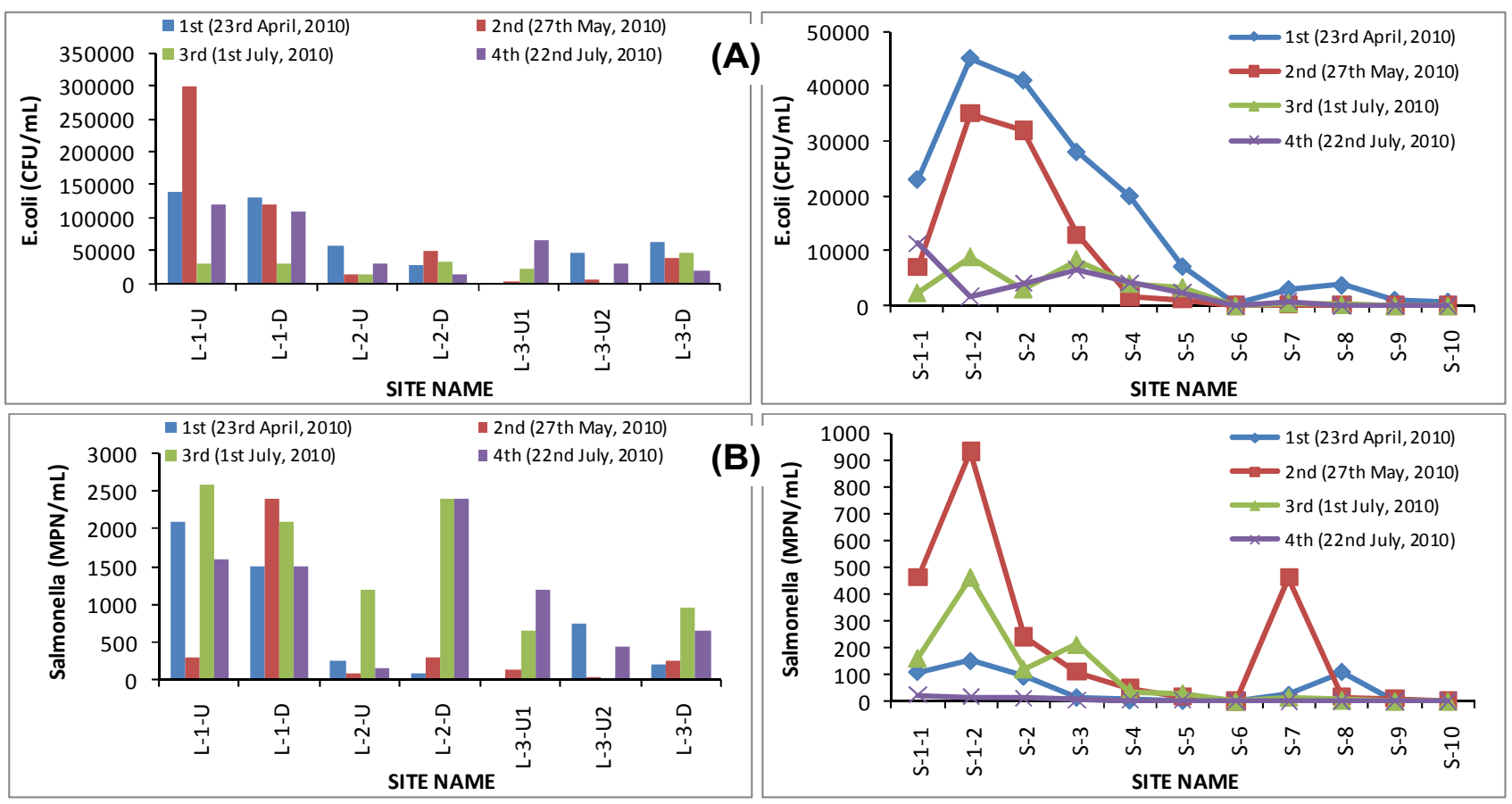

Fig. 9. E. coli (A) and Salmonella (B) amount in lagoon ditch slurry and wastewater stream samples from the WG area introduced to the MG River.

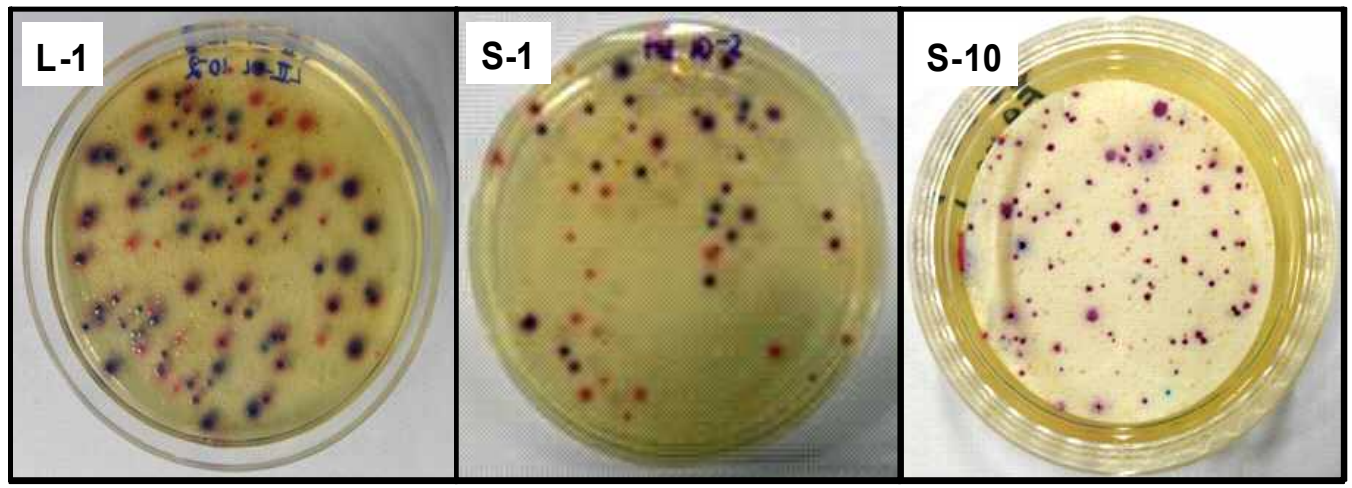

(A)

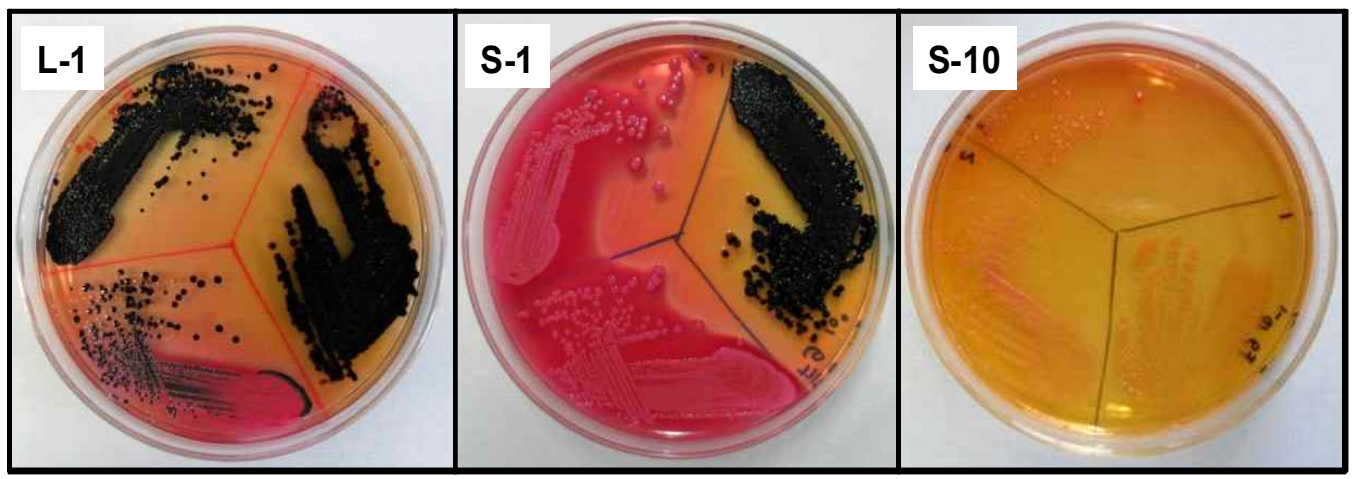

(B)

Fig. 10. E. coli(A) and Salmonella(B) selective agar plates showing the presence of respective colonies on lagoon ditch slurry and waste waster stream samples from WG area introduced into the MG River. 
along the flow down from the lagoon to the Iksan Stream because of dilution, sedimentation, and disinfection. Salmonella count in partially treated effluent at S-1-1 and untreated at S-1-2 was observed at 188 and $389 \mathrm{MPN} / \mathrm{mL}$, respectively. Salmonella should not be observed in the treated wastewater effluent because treated effluent generally discharged into the fresh water system, therefore this is a serious problem not only because it causes epidemic disease but also it alludes to other waterborne infection. At merge site (S-7) of two tributaries, Salmonella count was $12.5 \mathrm{MPN} / \mathrm{mL}$, which is a resultant mixture of $3.51 \times 10^{3} \mathrm{CFU} / \mathrm{mL}$ at $\mathrm{S}-5$ and none $\mathrm{MPN} / \mathrm{mL}$ at S-6 without intrusion of pig slurry. Salmonella concentration at S-9 was noticed about $2.3 \mathrm{MPN} / \mathrm{mL}$, which is potential bacterial pathogen entering into the $\mathrm{MG}$ River. As a result, complete removal of microbial pathogens should take place before any of it discharged into the water stream.

\section{CONCLUSIONS AND RECOMMENDATIONS}

The pollution of the Iksan Stream and the MG River caused by pig wastewater has been a major concern for the Korean government because the MG River is the main water source for the SaeManGeum (SMG) land. The MG River is connected to the the Iksan Stream which originates from WG pig farm clusters. The pollution levels of the lagoon ditches were measured by collecting ditch wastewater at L-1, L-2, and L-; the the Iksan Stream water (S-1 S-9); and the final MG River upstream water(S-0) and analyzed for physico- biochemical and pathogens quantity to figure out the pollution degree of those waterways.

All physicochemical constituents and pathogenic microbes, such as $\mathrm{COD}_{\mathrm{Cr}}, \mathrm{BOD}_{5}, \mathrm{TSS}, \mathrm{TN}, \mathrm{TP}$ and fecal coliforms at the effluent of WG Plant (S-1) exceed the effluent standard. This is mainly caused by the on-going renovations of WG Plant to increase the purification efficiency. Levels of the aforementioned constituents at the effluent site (S-1) will hopefully meet the standard when the renovation of the WG Plant is completed.

The comparison of water quality between S-5 (WG pig farm clusters) and S-6 (no pig farms) has been very interesting. The evidence clearly supports that the discharge of pig slurry has a great effect on the water quality in the WG area. While all physico-chemical parameters and microbes along the stream decreased due to sedimentation, biodegradation or dilution; an alarming problem was discovered: the existence of pathogenic microbe count $(E$. coli, Salmonella) in the lagoon wastewater and the stream water. Not only were high concentrations of these pathogens themselves found but potential existence of more serious pathogens could rise to more dangerous conditions.

According to the living standard, the levels of TSS, $\mathrm{BOD}_{5}$, and E. coli receive fairly poor grades. Due to the factors mentioned above, MG River should not be considered as a source of drinking water in the near future. Immediate attention from the appropriate authorities is required to protect the lagoon wastewater, the effluent of the WG Plant, and the Iksan Stream from further pollution.

The WG Plant should complete the renovation as soon as possible to meet the effluent standard for effluent of the WG Plant. Concurrently the Ministry of Environment has announced an action plan to reduce pollution sources by reducing as many pig farms as possible through talks with willing owners and providing them with reasonable compensation.

\section{ACKNOWLEDGEMENTS}

The authors would like to acknowledge the financial support from the Ministry of Environment, Korean Government, Project No. 0525-20100025. We also thank all the pig producers and officials of Iksan-si for hosting the collection of environmental parameters in the Wangoong area and Jeonbuk-do for providing with related data available.

\section{REFERENCES}

APHA. 2005. Standard Methods for the Examination of Water and Wastewater, 21st ed. American Public Health Association, Washington, D.C., U.S.A.

Bartram, J., Wayne, W., Carmichael, Chorus, I., Jones, G. and Olav Skulberg, M. 1999. Chapter 1. Introduction, In: Toxic Cyanobacteria in Water. A guide to their public health consequences, monitoring and management. World Health Organization. URL: WHO document, Accessed on 7th April 2011.

Begum, A., Ramaiah, M., Harikrishna, Khan, I. and Veena, K. 2009. Heavy metal pollution and chemical profile of Cauvery river water. E-Journal of Chemistry, 6:47-52.

Carpenter, S. R., Caraco, N. F., Correll, D. L., Howarth, R. W., Sharpley, A. N. and Smith, V. H. 1998. Nonpoint pollution of surface waters with phosphorous and nitrogen. Ecol. Appl. 8:559-568. 
Earl, S. R., Valett, H. M. and Webster, J. R. 2006. Nitrogen saturation in stream ecosystem. Ecology, 87:3140-3151.

EEA. 2003. Organic matters in river, European Environment Agency. http://www.eea.europa.eu/data-and-maps/indicators/organicmatter-in-rivers Accessed on 7th April 2011.

Hall, R. O. Jr. 2003. A stream's role in watershed nutrient export. Proc. Natl. Acad. Sci. U. S. A. 100:10137-10138.

Johnson, P. T. J., Chase, J. M., Dosch, K. L., Hartson, R. B. Gross, J. A., Larson, D. J., Sutherland, D. R. and Carpenter S. R. 2007. Aquatic eutrophication promotes infection in amphibians. Proc. Natl. Acad. Sci. U. S. A. 104:15781-15786.

McDowell, R. W. and Sharpley, A. N. 2003. Uptake and release of phosphorous from overland flow in a stream environment. J. Environ. Qual. 32:937-948.

Merseburger, G. C., Marti, E. and Sabater, F. 2005. Net changes in nutrient concentrations below a point source input in two streams draining catchments with contrasting land uses. Sci. Total Environ. 347:217-229.

Michaud, J. P. 1994. Measuring Total Suspended Solids and Turbidity in lakes and streams. A Citizen's Guide to Understanding and Monitoring Lakes and Streams. State of Washington, Department of Ecology.

Ministry of Environment, Republic of Korea, Major polices, Water
Quality and Water Ecosystems, Standards for Water quality Environment, Rivers and Streams. http://eng.me.go.kr/content.do? method $=$ moveContent\&menuCode $=$ pol_wat_sta_sta_rivers Accessed on 7th April 2011.

Strock, J. S., Dell, C. J. and Schmidt, J. P. 2007. Managing natural processes in drainage ditches for nonpoint source nitrogen control. J. Soil Water Conserv., 62:188-196.

Suresh, A., Choi, H. L., Lee, J. H., Zhu, K., Yao, H. Q., Choi, H. J., Moon, O. K., Park, C. K. and Kim, J. J. 2009a. Pig Slurry Characterization and Prediction Equations for Nutrients in South Korean Farms. Trans. ASABE 52:267-273.

Suresh, A., Choi, H. L., Oh, I. D. and Moon, O. K. $2009 \mathrm{~b}$. Prediction of the nutrients value and biochemical characteristics of pig slurry by measurement of EC-Electrical conductivity. Bioresour. Technol. 100:4683-4689.

WEPA. 2007. State of water, Republic of Korea, Water Environment partnership in Asia. http://www.wepa-db.net/ policies/state/southkorea/southkorea.htm Accessed on 7th April 2011.

Zhu, K., Choi, H. L., Yao, H. Q., Suresh, A. and Oh, D. I. 2009. Effects of Anaerobically digested pig slurry application on runoff and leachate. Chem. Ecol. 25:359-369.

(Received Apr. 19, 2011; Revised Jun. 21, 2011; Accepted Jul. 25, 2011) 